\title{
Supplementary prenatal copper increases plasma triiodothyronine and brown adipose tissue uncoupling protein-1 gene expression but depresses thermogenesis in newborn lambs
}

\author{
Stephen B. Smith ${ }^{1, *}$, Craig R. Sweatt ${ }^{1}$, and Gordon E. Carstens ${ }^{1}$
}

\author{
* Corresponding Author: Stephen B. Smith \\ Tel: +1-979-845-3939, Fax: +1-979-458-2702, \\ E-mail: sbsmith@tamu.edu \\ 'Department of Animal Science, Texas A\&M University, \\ College Station, TX 77843, USA \\ ORCID \\ Stephen B. Smith \\ https://orcid.org/0000-0002-2779-8281 \\ Gordon E. Carstens \\ https://orcid.org/0000-0001-7024-7162
}

Submitted Mar 3, 2018; Revised Jun 29, 2018; Accepted May 7, 2019
Objective: We tested the hypothesis that increasing dietary copper $(\mathrm{Cu})$ to gravid ewes would enhance brown adipose tissue (BAT) thermogenesis in their offspring.

Methods: Twin-bearing ewes were assigned on $\mathrm{d} 70$ of gestation to diets containing 3, 10, or $20 \mathrm{ppm}$ dietary $\mathrm{Cu}\left(\mathrm{n}=8\right.$ per group). Twin lambs were assigned at birth to a cold $\left(6^{\circ} \mathrm{C}\right)$ or warm $\left(28^{\circ} \mathrm{C}\right)$ environmental chamber for $48 \mathrm{~h}$. Blood was collected from ewes and from lambs and perirenal BAT was collected after $48 \mathrm{~h}$ in the environmental chambers.

Results: Prenatal $\mathrm{Cu}$ exposure increased ewe plasma triiodothyronine $\left(\mathrm{T}_{3}\right)$ and thyroxine concentration $\left(\mathrm{T}_{4}\right)(\mathrm{p}<0.01)$ but prenatal $\mathrm{Cu}$ exposure had no effect on lamb plasma concentrations of $\mathrm{T}_{3}, \mathrm{~T}_{4}$, glucose, or nonesterified fatty acid concentration $(\mathrm{p} \geq 0.08)$. The high level of prenatal $\mathrm{Cu}$ exposure depressed 48 -h rectal temperature $(\mathrm{p}=0.03)$. Cold exposure decreased BAT norepinephrine (NE) and increased BAT dopamine $(\mathrm{p} \leq 0.01)$, but prenatal $\mathrm{Cu}$ exposure had no effect on BAT cytochrome $\mathrm{C}$ oxidase activity or BAT NE or dopamine ( $\mathrm{p} \geq 0.07)$. However, BAT of lambs from high-Cu ewes maintained higher uncoupling protein-1 (UCP1) gene expression than BAT of lambs from low- and medium-Cu ewes following warm or cold exposure in environmental chambers $(\mathrm{p}=0.02)$. Cold exposure caused near depletion of BAT lipid by $48 \mathrm{~h}(\mathrm{p}<0.001)$, increased BAT cytochrome $\mathrm{c}$ oxidase activity ( $\mathrm{p}<$ $0.01)$, and depressed plasma fatty acid concentrations $(\mathrm{p}<0.001)$.

Conclusion: Although prenatal $\mathrm{Cu}$ exposure increased BAT UCP1 expression during warm and cold exposure, prenatal cold $\mathrm{Cu}$ exposure depressed 48 -h rectal temperature. Cold exposure decreased BAT lipid content by over $80 \%$ and decreased lamb plasma fatty acid concentration by over $40 \%$, indicating that fuel reserves for thermogenesis were nearly depleted by $48 \mathrm{~h}$ of cold exposure.

Keywords: Brown Adipose Tissue; Copper; Lambs; Thermogenesis; Uncoupling Protein-1

\section{INTRODUCTION}

Approximately one-half of maximal thermogenic response to cold stress in newborn lambs is derived from nonshivering thermogenesis of brown adipose tissue (BAT) [1]. The ability of BAT to generate heat is due to the presence of uncoupling protein-1 (UCP1), found only in BAT mitochondria. When stimulated by cold exposure, UCP1 acts to uncouple oxidative phosphorylation from fatty acid oxidation, thereby causing BAT mitochondria to generate heat rather than ATP. Brown adipose tissue is highly innervated by the sympathetic nervous system [2] which, during cold exposure, releases norepinephrine (NE) to activate BAT thermogenesis by stimulating fatty acid oxidation and UCP1 gene expression. Additionally, NE activates type II thyroxine 5'deiodinase in BAT to convert thyroxine $\left(\mathrm{T}_{4}\right)$ to the more active thyroid hormone triiodothyronine $\left(\mathrm{T}_{3}\right)$ [3]. Local synthesis of $\mathrm{T}_{3}$ is also an important reg- 
ulator of $U C P 1$ gene expression [4]. Thus, both $\mathrm{NE}$ and $\mathrm{T}_{3}$ play a critical role in regulating BAT thermogenesis in newborn lambs.

Eales et al [5] reported that newborn lambs that were hypothermic due to cold exposure had low plasma $\mathrm{Cu}$ concentrations $(0.18 \mu \mathrm{g} / \mathrm{mL})$ compared to plasma $\mathrm{Cu}$ concentrations in lambs that did not display hypothermia $(0.63 \mu \mathrm{g} / \mathrm{mL})$, which suggests that maternal $\mathrm{Cu}$ deficiency may impair the cold tolerance of newborn lambs. There are several $\mathrm{Cu}$-dependent enzyme systems that play critical roles in regulating BAT thermogenesis, including cytochrome $\mathrm{c}$ oxidase (COX; electron transport system) and dopamine- $\beta$-hydroxylase (conversion of dopamine to NE in the sympathetic nervous system). Additionally, Lukaski et al [6] reported that $\mathrm{Cu}$ deficiency in rats reduced plasma $\mathrm{T}_{3}$ and $\mathrm{T}_{4}$ concentrations and reduced BAT deiodinase activity, resulting in hypothermia. Therefore, we hypothesized that increasing dietary $\mathrm{Cu}$ to gravid ewes would enhance BAT thermogenesis in their offspring.

\section{MATERIALS AND METHODS}

\section{Ethics statement}

The experimental procedures were approved by the Texas A\&M University Animal Care and Use Committee of the Office of Research Compliance.

\section{Animals and diets}

Twenty-four Rambouillet ewes were determined to be twinbearing by ultrasound during the first trimester of gestation. Ewes were housed in an open-sided barn, and provided free access to fresh water and coastal bermudagrass hay containing $0.76 \mathrm{mg} \mathrm{Cu} / \mathrm{kg} \mathrm{DM}$. Ewes were adapted to a high-concentrate diet for $3 \mathrm{wk}$ (Table 1, without supplemental S, Mo, or $\mathrm{Cu}$ ) that was formulated to meet $\mathrm{NRC}$ requirements [7], with the exception of $\mathrm{Cu}$. Thereafter, ewes were assigned on approximately d 50 of gestation to 1 of 3 diets containing 3,10 , or 20 ppm dietary $\mathrm{Cu}$ ( $\mathrm{n}=8$ lambs per $\mathrm{Cu}$ concentration). Additionally, each diet contained $2 \mathrm{ppm}$ (DM basis) Mo and $0.28 \%$ $\mathrm{S}$ to limit the absorption of dietary $\mathrm{Cu}$. Accounting for the dietary concentrations of $\mathrm{Mo}$ and $\mathrm{S}$, the net available $\mathrm{Cu}$ concentrations [8] were $0.12,0.36$ and $0.72 \mathrm{ppm}$ (DM basis) for the low-, medium- and high-Cu diets, respectively. The medium-Cu treatment was formulated to meet the estimated net available $\mathrm{Cu}$ requirements for $75 \mathrm{~kg}$ twin-bearing ewes, which is $0.63 \mathrm{mg} \mathrm{Cu} / \mathrm{d}$ [8]. Each prenatal Cu treatment consisted of 4 ewes/pen and 2 pens/treatment. Ewes were fed individually in an open-sided barn. Food intake and body weight were measured at 7-d intervals. Food intake was calculated as total food provided minus food remaining.

Ewes were monitored at 4-h intervals prior to expected lambing. Immediately following parturition, lambs were separated from ewes, dried of amniotic fluid, weighed, and
Table 1. Ingredient and nutrient composition of experimental diets

\begin{tabular}{lccc}
\hline Items & Low Cu & Medium Cu & High Cu \\
\hline Ingredient (\% as fed) & & & \\
Corn & 38.99 & 38.98 & 38.98 \\
Cottonseed hulls & 34.68 & 34.68 & 34.68 \\
Rice meal feed & 18.97 & 18.97 & 18.97 \\
Meat and bone meal & 4.68 & 4.68 & 4.68 \\
Cottonseed meal & 1.50 & 1.50 & 1.50 \\
Ca-SO & 0.53 & 0.53 & 0.53 \\
Limestone & 0.29 & 0.29 & 0.29 \\
Salt & 0.225 & 0.225 & 0.225 \\
Vitamins A, D, E & 0.124 & 0.124 & 0.124 \\
Na-Mo & 0.001 & 0.001 & 0.001 \\
Cu-lysine & 0 & 0.014 & 0.034 \\
Nutrients (DM basis) & & & \\
DM (\%) & 89.0 & 89.0 & 89.0 \\
CP (\%) & 12.3 & 12.3 & 12.3 \\
ADF (\%) & 31.57 & 31.61 & 31.58 \\
Ca (\%) & 0.96 & 0.96 & 0.96 \\
P (\%) & 0.69 & 0.69 & 0.69 \\
S (\%) & 0.28 & 0.28 & 0.28 \\
Mo (ppm) & 2.0 & 2.0 & 2.0 \\
Cu (ppm) & 3.25 & 10.43 & 20.73 \\
\hline
\end{tabular}

moved to a warm chamber $\left(25^{\circ} \mathrm{C}\right)$. Initial blood samples were obtained by venipuncutre and lambs were fed $38 \mathrm{~mL} / \mathrm{kg}$ BW pooled bovine colostrum. At $2 \mathrm{~h}$ of age, lambs were assigned randomly within twin pair to cold $\left(6^{\circ} \mathrm{C}\right)$ or warm $\left(28^{\circ} \mathrm{C}\right)$ environmental chambers for $48 \mathrm{~h}$. At 8,14 , and $20 \mathrm{~h}$ of age, lambs were fed $30 \mathrm{~mL} / \mathrm{kg} \mathrm{BW}$ colostrum. Rectal temperatures were measured at $48 \mathrm{~h}$. Blood was collected obtained by jugular venipuncture in heparinized vacutainer tubes from ewes at 7 $\mathrm{d}$ prior to birth between 0700 and 0800 before feeding and from lambs prior to slaughter at $48 \mathrm{~h}$ of age, and plasma was analyzed for $\mathrm{Cu}$, ceruloplasmin, $\mathrm{T}_{3}, \mathrm{~T}_{4}$, and cortisol. Glucose and nonesterified fatty acids (NEFA) also were measured in lamb plasma. Blood samples were obtained by jugular venipuncture in heparinized vacutainer tubes between 0700 and 0800 , before feeding. Equal volumes of $0.9 \%$ saline were infused to replace blood volume.

\section{Collection of brown adipose tissue}

Following the 48-h environmental-chamber period, lambs were administered an overdose of sodium pentobarbital and exsanguinated, and perirenal BAT was removed completely and weighed. A portion of the BAT was snap-frozen in liquid nitrogen and stored at $-80^{\circ} \mathrm{C}$.

\section{Histological analysis}

Small, unfrozen samples of BAT ( 100 mg) were prepared for histological analysis. Tissue samples were sliced into 1-mm size pieces and placed into a primary fixative of $3 \%$ glutaraldehyde:0.08 $M$ sodium cacodylate buffer ( $\mathrm{pH}$ 7.4). One 
perirenal BAT sample from a low-Cu, warm-chamber lamb, and one sample from a high-Cu, cold-chamber lamb were post-fixed in $20 \mathrm{~g} / \mathrm{L}$ osmium tetroxide, stained with enbloc stain (2\% uranylacetate in methanol), and embedded in Epon/ Araldite [9]. The embedded samples were sectioned to approximately $70-\mathrm{nm}$ thickness and photographed at $60 \mathrm{kV}$ with a transmission electron microscope (Zeiss 10 C, Germany).

\section{Preparation and analysis of RNA}

Total RNA was isolated from previously snap-frozen perirenal BAT as described previously [10]. Purity and yield were determined by the ratio of absorbances at 260 and $280 \mathrm{~nm}$, which exceed 1.8 for all samples. A UCP1 cDNA was generated by polymerase chain reaction. The template DNA was the bovine calf UCP1 1.4-kb cDNA (generously provided by L. Casteilla, Centre de Rechere, CNRS, France) linearized with EcoR1. The primers were 5'-CTC AGC GGG CCT AAC GAC$3^{\prime}$ and $5^{\prime}$-GTT TGT TTT TCA CCA GGG-3'. UCP1 mRNA was determined by slot blot analysis as described previously [10].

\section{Isolation of mitochondria}

Mitochondria were isolated by differential centrifugation as described by Cannon and Lindberg [11]. Fresh, unfrozen BAT samples were dissected and washed immediately in sucrose buffer $(250 \mathrm{mmol} / \mathrm{L}$ sucrose, $5 \mathrm{mmol} / \mathrm{L} \mathrm{TES}-\mathrm{HCl}$, $\mathrm{pH}$ 7.2). BAT samples were homogenized in 10 volumes (wt/vol) of sucrose buffer and centrifuged at $800 \times \mathrm{g}$ for 10 $\mathrm{min}$. The pellet was resuspended to original volume in fresh sucrose buffer. The suspension was centrifuged at $800 \times g$ for $10 \mathrm{~min}$ to sediment nuclei and cellular debris, and the supernate was centrifuged at $10,000 \times g$ for $10 \mathrm{~min}$. The mitochondria pellet was resuspended to $0.5 \mathrm{~mL}$ in fresh sucrose buffer. Aliquots of homogenate and mitochondrial preparations were frozen at $-80^{\circ} \mathrm{C}$ for subsequent determination of COX activity [12], DNA [13], protein [14], and lipid [10]. Total mitochondrial protein was determined based on mitochondrial recovery from preparations.

\section{Plasma $\mathrm{Cu}$, hormones, and nonesterified fatty acids}

Plasma $\mathrm{Cu}$ was determined by flame atomic absorption spectrophotometry (Model S 11, Thermo Jarrell Ash, Franklin, MA, USA). Blood samples were centrifuged at 2,000 $\times \mathrm{g}$ and plasma harvested and stored at $-20^{\circ} \mathrm{C}$. Plasma ceruloplasmin activity was measured as described previously [15]. Plasma NEFA were measured with a commercial kit (Wako Chemicals, Brentwood, NY, USA). Concentrations of $\mathrm{T}_{3}, \mathrm{~T}_{4}$, and cortisol were measured using commercial radioimmunoassay kits (Pantex, Santa Monica, CA, USA). Dopamine and $\mathrm{NE}$ were measured by high-performance liquid chromatography [16].

\section{Source of chemicals}

Unless otherwise stated, biochemicals were purchased from Sigma Chemical (St. Louis, MO, USA) and Gibco BRL (Gaithersburg, MD, USA). Radiolabeled materials were obtained from Amersham (Arlington Heights, IL, USA).

\section{Analysis of data}

The data were analyzed using the Proc Mixed model for analysis of variance to obtain main effects means, subclass means, and standard errors [17]. For ewe performance data, fixed effect was $\mathrm{Cu}$ treatment and random effects were ewe and pen; pen was the experimental unit. For lamb data, fixed effects were prenatal $\mathrm{Cu}$ treatment and chamber temperature and random effect was lamb. Lambs were housed individually in chambers and individual lamb was the experimental until. The three-way interaction of prenatal dietary $\mathrm{Cu}$ (low, medium, and high), chamber temperature $\left(6^{\circ} \mathrm{C}\right.$ and $\left.25^{\circ} \mathrm{C}\right)$ and time in chamber $(0$ and $48 \mathrm{~h})$ was not significant for rectal temperature, body weight, or any plasma dependent variables. Therefore, the data for lamb body weight, rectal temperature, and lamb plasma dependent variables (as well as BAT dependent variables) were analyzed as a $2 \times 2$ factorial with prenatal dietary $\mathrm{Cu}$ and chamber temperature as the main effects; the model also tested the $\mathrm{Cu} \times$ chamber temperature two-way interactions.

\section{RESULTS}

\section{Ewes}

There was no difference in initial or final body weight, average daily again, or dry matter intake in ewes in response to increasing concentrations of dietary $\mathrm{Cu}(\mathrm{p} \geq 0.19$; Table 2). Dietary $\mathrm{Cu}$ treatment had no effect on plasma ceruloplasmin activity and $\mathrm{Cu}$ concentration in ewes $(\mathrm{p} \geq 0.11)$ (Table 3 ). Plasma $\mathrm{T}_{3}$ and $\mathrm{T}_{4}$ concentrations were higher $(\mathrm{p}<0.01)$ in ewes fed the high-Cu diet than in ewes fed the low-Cu diet.

\section{Effects of prenatal $\mathrm{Cu}$ and cold exposure on lambs} Chamber temperature had no effect on plasma $\mathrm{Cu}$ concentration or ceruloplasmin activity ( $p>0.25)$, so data for these variables were pooled between warm and cold chamber tem-

Table 2. Growth and intake of ewes fed three levels of dietary copper

\begin{tabular}{lccccc}
\hline Items & $\begin{array}{c}\text { Low } \\
\mathbf{C u}^{1)}\end{array}$ & $\begin{array}{c}\text { Medium } \\
\mathbf{C u}^{1)}\end{array}$ & $\begin{array}{c}\text { High } \\
\mathbf{C u}^{1)}\end{array}$ & SEM & p-values \\
\hline Initial body weight $(\mathrm{kg})$ & 60.3 & 59.8 & 59.8 & 2.4 & $>0.25$ \\
Final body weight (kg) & 78.1 & 75.7 & 76.3 & 2.7 & $>0.25$ \\
ADG (kg/d) & 0.20 & 0.20 & 0.21 & 0.04 & $>0.25$ \\
DMI (kg/d) & 1.78 & 1.69 & 1.67 & 0.04 & 0.19 \\
\hline
\end{tabular}

SEM, standard error of the mean; ADG, average daily gain; DMI, dry matter intake (individual intake).

1) Low, medium, and high Cu: 3.2, 10, and 20 ppm Cu (DM basis), respectively. 
Table 3. Plasma $\mathrm{Cu}$, ceruloplasmin, and thyroid hormones in ewes and plasma $\mathrm{Cu}$ and ceruloplasmin in lambs following prenatal treatment with three levels of dietary copper

\begin{tabular}{|c|c|c|c|c|c|}
\hline Items & Low $\mathrm{Cu}^{1)}$ & Medium $\mathrm{Cu}^{1)}$ & High $\mathrm{Cu}^{11}$ & SEM & $p$-values \\
\hline \multicolumn{6}{|l|}{ Ewes } \\
\hline $\mathrm{Cu}(\mu \mathrm{g} / \mathrm{mL})$ & 1.03 & 1.01 & 1.10 & 0.04 & 0.11 \\
\hline Ceruloplasmin (IU) & 27.6 & 27.8 & 26.8 & 0.94 & $>0.25$ \\
\hline Triiodothreonine (ng/dL) & $196^{b}$ & $243^{a b}$ & $296^{a}$ & 19 & $<0.001$ \\
\hline Thyroxine ( $\mu \mathrm{g} / \mathrm{dL})$ & $7.58^{b}$ & $10.58^{\mathrm{ab}}$ & $12.23^{\mathrm{a}}$ & 1.17 & $<0.01$ \\
\hline \multicolumn{6}{|l|}{ Lamb (at birth) } \\
\hline $\mathrm{Cu}(\mu \mathrm{g} / \mathrm{mL})$ & 0.41 & 0.35 & 0.39 & 0.04 & $>0.25$ \\
\hline Ceruloplasmin (IU) & 2.58 & 2.14 & 3.04 & 0.10 & $>0.25$ \\
\hline \multicolumn{6}{|l|}{ Lamb (at 48 h) $)^{2)}$} \\
\hline $\mathrm{Cu}(\mu \mathrm{g} / \mathrm{mL})$ & 0.38 & 0.32 & 0.24 & 0.04 & $>0.25$ \\
\hline Ceruloplasmin (IU) & $5.18^{b}$ & $7.59^{\mathrm{ab}}$ & $9.88^{\mathrm{a}}$ & 0.14 & 0.05 \\
\hline
\end{tabular}

SEM, standard error of the mean; ADG, average daily gain; DMI, dry matter intake (individual intake).

1) Low, medium, and high Cu: 3.2, 10, and 20 ppm Cu (DM basis), respectively.

2) Chamber temperature had no effect on plasma Cu or ceruloplasmin activity $(p>0.25)$, so data for these variables was pooled between warm and cold chamber temperatures.

${ }^{3)}$ Plasma ceruloplasmin activity increased with age for all prenatal Cu treatment groups $(p<0.001)$.

a,b Values within a row with common superscripts do not differ $(p>0.05)$.

peratures (Table 3). At birth, there were no differences among prenatal $\mathrm{Cu}$ treatments for $\mathrm{Cu}$ concentration or ceruloplasmin activity ( $\mathrm{p}>0.25)$. Plasma ceruloplasmin activity increased with age for all prenatal $\mathrm{Cu}$ treatment groups $(\mathrm{p}<0.001)$, and ceruloplasmin activity was greater in lambs from high-Cu ewes than in lambs from low-Cu ewes $(\mathrm{p}=0.05)$.

Prenatal $\mathrm{Cu}$ exposure, chamber temperature, and the $\mathrm{Cu} \times$ temperature interaction were not significant for lamb body weight ( $>0.25)$ (Table 4). Rectal temperature at birth $\left(38.6^{\circ} \mathrm{C}\right.$ $\pm 0.31^{\circ} \mathrm{C}$ ) was not different among prenatal $\mathrm{Cu}$ treatments ( $\mathrm{p}$ $>0.25$; data not shown). Rectal temperature was lower ( $\mathrm{p}<$ 0.001 ) in cold-exposed than in warm-exposed lambs and the high level of prenatal $\mathrm{Cu}$ exposure depressed rectal temperature $(\mathrm{p}=0.03)$ (Table 4$)$.

Lamb plasma $\mathrm{T}_{3}$ concentration tended $(\mathrm{p}=0.08)$ to decrease as prenatal $\mathrm{Cu}$ level increased (Table 4 ) and plasma $\mathrm{T}_{3}$ concentration was greater $(\mathrm{p}<0.001)$ in cold-exposed lambs than in warm-exposed lambs. Lamb plasma $\mathrm{T}_{4}$ concentration was unaffected by prentatal $\mathrm{Cu}$ or environmental temperature ( $p>0.25)$. Lamb plasma cortisol concentration was higher $(p<0.001)$ in cold-exposed than warm-exposed lambs. The cold-induced increase in plasma cortisol concentrations was greater in lambs born to high-Cu ewes than in lambs born to low-Cu ewes (prenatal $\mathrm{Cu} \times$ temperature interaction $\mathrm{p}=0.05$ ). Cold-exposed lambs had lesser plasma NEFA concentration than warm-exposed lambs $(\mathrm{p}<0.001)$. Plasma glucose concentration was unaffected $(\mathrm{p}>0.25)$ by prenatal $\mathrm{Cu}$ or postnatal temperature treatments.

Postnatal cold exposure decreased $(\mathrm{p}<0.001)$ BAT mass and lipid concentration and increased $(\mathrm{p}<0.01)$ BAT protein and moisture concentration, mitochondrial protein concentration, and cytochrome $\mathrm{c}$ oxidase activity (Table 5), regardless of prenatal $\mathrm{Cu}$ treatment. Postnatal cold exposure decreased $(\mathrm{p}<0.01)$ BAT NE concentration and increased $(\mathrm{p}<0.001)$ BAT

Table 4. Lamb body weight, rectal temperature, and plasma hormone and metabolite concentrations following $48 \mathrm{~h}$ in warm or cold environmental chambers for lambs following prenatal exposure to three levels of dietary copper

\begin{tabular}{|c|c|c|c|c|c|c|c|c|c|c|}
\hline \multirow{3}{*}{ Items } & \multicolumn{6}{|c|}{ Dietary Cu concentration $^{11)}$} & \multirow{3}{*}{ SEM } & \multirow{2}{*}{\multicolumn{3}{|c|}{ p-values }} \\
\hline & \multicolumn{2}{|c|}{ Low Cu } & \multicolumn{2}{|c|}{ Medium Cu } & \multicolumn{2}{|c|}{ High Cu } & & & & \\
\hline & Warm & Cold & Warm & Cold & Warm & Cold & & $\mathrm{Cu}$ & Temp & CuxTemp \\
\hline Rectal temperature $\left({ }^{\circ} \mathrm{C}\right)$ & 39.0 & 37.8 & 39.0 & 36.9 & 38.0 & 35.9 & 0.3 & 0.03 & $<0.001$ & $>0.25$ \\
\hline Triiodothreonine (ng/dL) & 145 & 251 & 111 & 208 & 103 & 187 & 13 & 0.08 & $<0.001$ & $>0.25$ \\
\hline Thyroxine ( $\mu \mathrm{g} / \mathrm{dL})$ & 6.18 & 8.77 & 5.99 & 8.58 & 5.77 & 9.56 & 0.38 & $>0.25$ & $>0.25$ & $>0.25$ \\
\hline Fatty acids $(\mu \mathrm{Eq} / \mathrm{L})$ & 457.7 & 244.6 & 403.5 & 267.1 & 504.1 & 263.7 & 22.3 & $>0.25$ & $<0.001$ & $>0.25$ \\
\hline Glucose (mg/dL) & 40.9 & 38.0 & 35.5 & 32.2 & 39.0 & 24.1 & 4.2 & $>0.25$ & $>0.25$ & $>0.25$ \\
\hline
\end{tabular}

SEM, standard error of the mean.

1) Low, medium, and high Cu: $3.2,10$, and $20 \mathrm{ppm}$ Cu (DM basis), respectively; warm, $28^{\circ} \mathrm{C}$, cold, $6^{\circ} \mathrm{C}$ temperature exposure.

${ }^{a-c}$ Values within a row with common superscripts do not differ $(p>0.05)$. 
Table 5. Brown adipose tissue mass, composition, norepinephrine and dopamine concentrations, and cytochrome c oxidase activity at $48 \mathrm{~h}$ of age in lambs following prenatal exposure to three levels of dietary copper

\begin{tabular}{|c|c|c|c|c|c|c|c|c|c|c|}
\hline \multirow{3}{*}{ Brown adipose tissue item } & \multicolumn{6}{|c|}{ Dietary Cu concentration ${ }^{1)}$} & \multirow{3}{*}{ SEM } & \multirow{2}{*}{\multicolumn{3}{|c|}{ p-values }} \\
\hline & \multicolumn{2}{|c|}{ Low Cu } & \multicolumn{2}{|c|}{ Medium Cu } & \multicolumn{2}{|c|}{ High Cu } & & & & \\
\hline & Warm & Cold & Warm & Cold & Warm & Cold & & $\mathrm{Cu}$ & Temp & CuxTemp \\
\hline \multicolumn{11}{|l|}{ Composition (mg/g BAT) } \\
\hline Lipid & 436.8 & 80.3 & 453.1 & 79.7 & 376.5 & 74.7 & 28.0 & $>0.25$ & $<0.001$ & $>0.25$ \\
\hline DNA & $3.34^{c}$ & $4.14^{b}$ & $3.27^{c}$ & $4.41^{b}$ & $3.47^{\mathrm{bc}}$ & $5.53^{\mathrm{a}}$ & 0.20 & $<0.001$ & $<0.001$ & $<0.01$ \\
\hline Mitochondrial protein ( $\mu \mathrm{g} / \mathrm{g}$ BAT) & 23.58 & 38.53 & 25.34 & 33.63 & 23.76 & 37.26 & 2.70 & $>0.25$ & $<0.01$ & $>0.25$ \\
\hline $\begin{array}{l}\text { Cytochrome c oxidase activity } \\
(\mu \mathrm{mol} /[\mathrm{min} \cdot \mathrm{g} B A T])\end{array}$ & 49.2 & 160.9 & 60.4 & 157.0 & 53.5 & 145.5 & 12.5 & $>0.25$ & $<0.01$ & $>0.25$ \\
\hline Norepinephrine ( $\mu \mathrm{g} / \mathrm{g}$ BAT) & 1.45 & 0.97 & 1.19 & 0.74 & 0.95 & 0.82 & 0.13 & 0.07 & $<0.01$ & $>0.25$ \\
\hline
\end{tabular}

SEM, standard error of the mean; BAT, brown adipose tissue.

1) Low, medium, and high Cu: $3.2,10$, and $20 \mathrm{ppm} \mathrm{Cu}$ (DM basis), respectively; warm, $28^{\circ} \mathrm{C}$, cold, $6^{\circ} \mathrm{C}$ temperature exposure.

a-c Values within a row with common superscripts do not differ $(p>0.05)$.

dopamine concentration. The increase in BAT dopamine concentration was significant only for lambs born to high- $\mathrm{Cu}$ ewes (prenatal $\mathrm{Cu} \times$ temperature interaction $\mathrm{p}=0.04$ ).

Relative UCP1 gene expression was higher $(\mathrm{p}<0.001)$ in BAT from cold-exposed lambs than in BAT from warm-exposed lambs; UCP1 gene expression was virtually undetectable in BAT from lambs held at $28^{\circ} \mathrm{C}$, except for BAT from high-Cu lambs (Figure 1). UCP1 gene expression was higher in BAT of lambs from high-Cu ewes than in BAT of lambs from lowand medium-Cu ewes $(\mathrm{p}=0.02)$. The increase in $U C P 1$ gene expression due to cold exposure was not affected by prenatal $\mathrm{Cu}$ treatment (prenatal $\mathrm{Cu} \times$ chamber temperature interaction $\mathrm{p}>0.25$ ).

\section{Lamb brown adipose tissue morphology}

Transmission electron micrographs were generated only for the two temperature/Cu extremes, i.e., warm-exposed lambs from low- $\mathrm{Cu}$ ewes and cold-exposed lambs from high-Cu ewes. Brown adipocytes from warm-exposed lambs contained large, central lipid droplets, whereas brown adipocytes from cold-exposed lambs contained virtually no visible lipid droplets (Figure 2). The cristae of mitochondria from cold-exposed lambs were more evident than cristae in mitochondria of warm-exposed lambs.

\section{DISCUSSION}

An early report [5] suggested that increasing maternal dietary $\mathrm{Cu}$ may attenuate hypothermia in lambs during cold exposure. Because several $\mathrm{Cu}$-dependent enzyme systems are involved in regulating BAT thermogenesis, including COX and dopamine- $\beta$-hydroxylase, we hypothesized that increas- ing $\mathrm{Cu}$ intake in gravid ewes would improve cold tolerance in newborn lamb. However, opposite to our hypothesis, increased $\mathrm{Cu}$ intake by ewes resulted in more rapid heat loss in

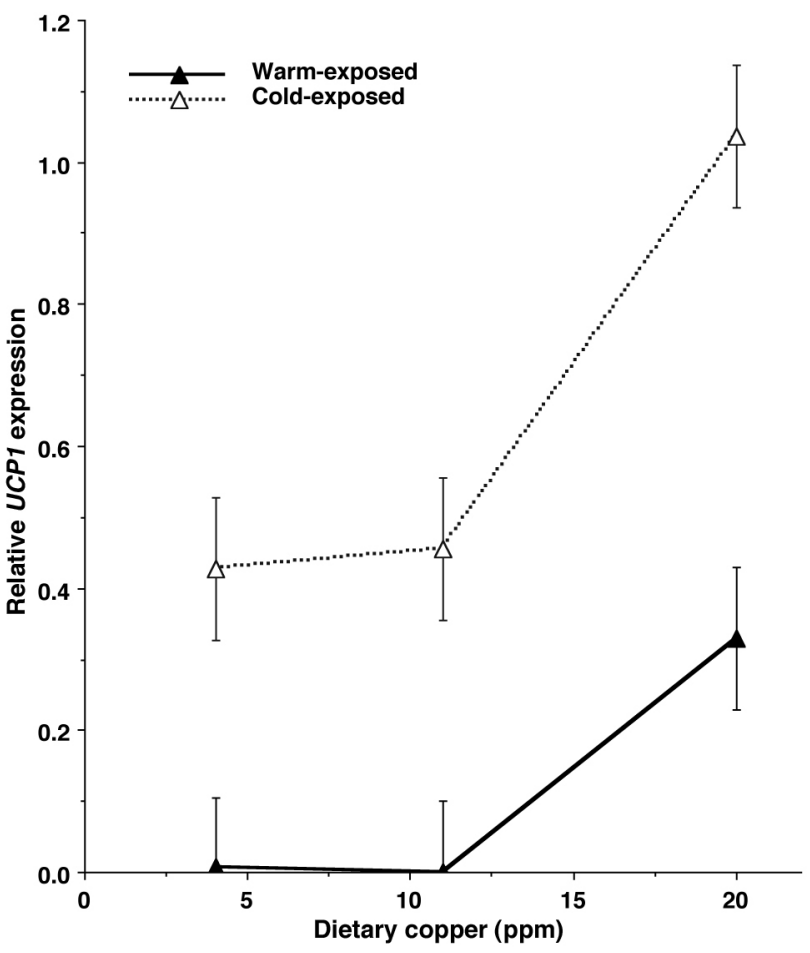

Figure 1. Relative UCP1 expression for mRNA from brown adipose tissue of lambs from ewes fed low (3.2 ppm), medium (10 ppm), or high (20 ppm) Cu during the last two trimesters of gestation. UCP1, uncoupling protein-1. Lambs were held at $6^{\circ} \mathrm{C}$ (cold) or $28^{\circ} \mathrm{C}$ (warm) temperatures for $48 \mathrm{~h}$ postnatally. Prenatal Cu effect $p=0.02$; postnatal temperature effect (warm vs cold) $p<0.001$; prenatal $\mathrm{Cu} X$ postnatal temperature interaction $p>0.25$. Pooled standard error bars for each treatment are attached to the symbols. 

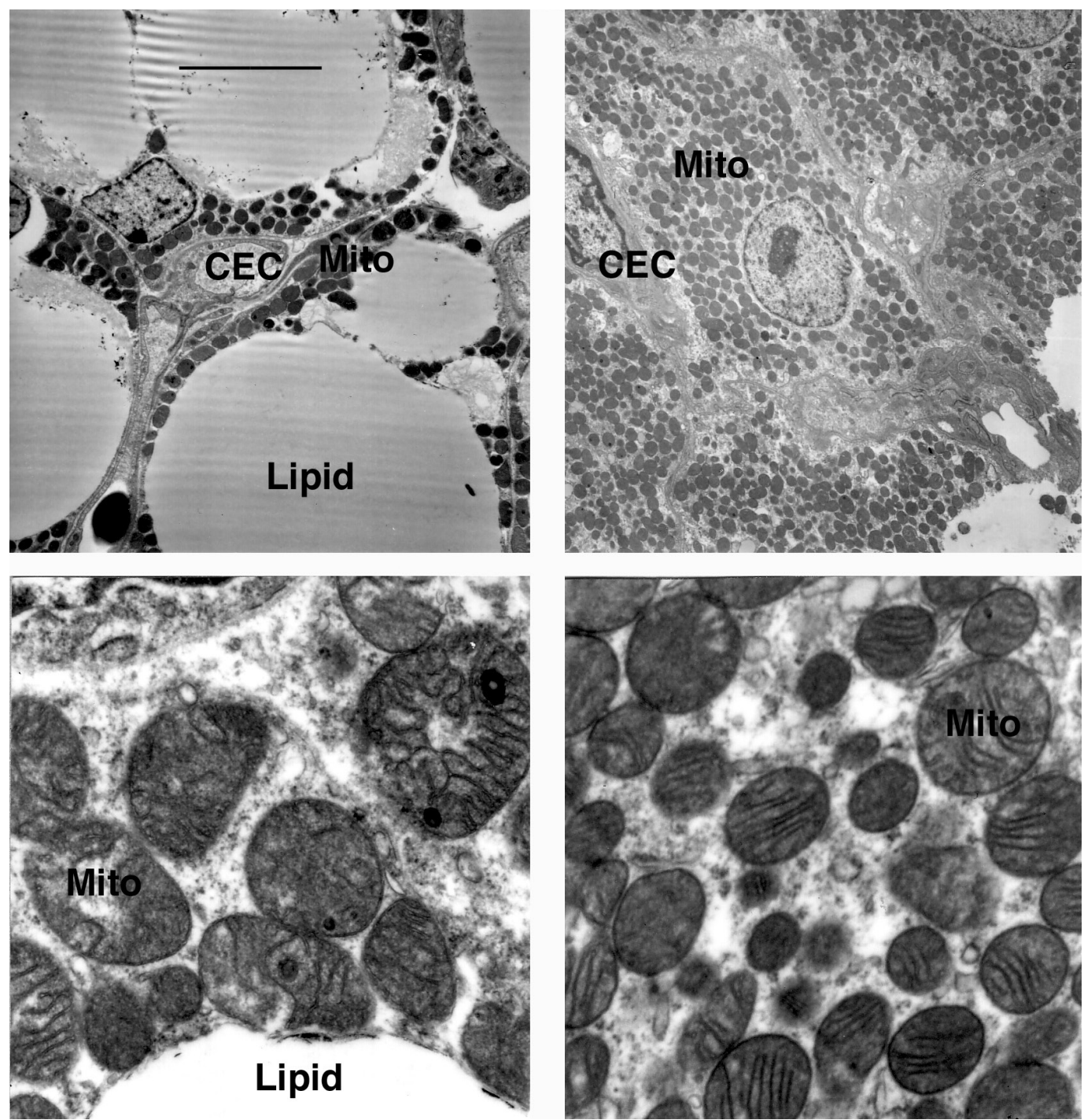

Figure 2. Electron microscopy of perirenal brown adipose tissue from newborn lambs exposed to $28^{\circ} \mathrm{C}$ (left) or $6^{\circ} \mathrm{C}$ (right) for $48 \mathrm{~h}$ postnatally. CEC, capillary endothelial cell; M, mitochondrion; lipid, lipid vacuole. Top, $\times 2,500$; bottom, $\times 25,000$. Scale bar in the upper left panel indicates $50 \mu$ m at 2,500×magnification

cold-exposed lambs, which may have been caused by increased $U C P 1$ expression in lambs from high-Cu ewes.

\section{Copper status}

The net availabilities of $\mathrm{Cu}$ were estimated to be $0.12,0.36$, and $0.72 \mathrm{mg} \mathrm{Cu} / \mathrm{kg} \mathrm{DM}$ for the low-, medium- and high- $\mathrm{Cu}$ prenatal treatments, respectively [8]. Based on ewe dry matter intake, net $\mathrm{Cu}$ intakes for the three treatments were 0.21 , 0.62 , and $1.22 \mathrm{mg} / \mathrm{d}$, respectively. Estimated net $\mathrm{Cu}$ requirements for $75-\mathrm{kg}$ twin-bearing ewes during late gestation are $0.63 \mathrm{mg} \mathrm{Cu} / \mathrm{d}$ [8]. Thus, dietary $\mathrm{Cu}$ concentration was adequate for the medium-Cu ewes, and deficient and excessive for low- and high-Cu ewes, respectively. However, the prenatal $\mathrm{Cu}$ treatments had no effect on plasma $\mathrm{Cu}$ concentration of the ewes and lambs, which would suggest that the ewes likely had adequate hepatic $\mathrm{Cu}$ stores prior to entry into the study.
Previous research [18] demonstrated that plasma Cu concentration and ceruloplasmin activity are low at birth and increase early postnatally, and the current study also demonstrated a postnatal increase in ceruloplasmin activity. Thus, by all measures, neither the ewes fed the low-Cu diets nor their lambs were $\mathrm{Cu}$-deficient.

\section{Thyroid hormones and brown adipose tissue} thermogenesis

Rapid accumulation of lipid in fetal lamb perirenal BAT occurs from $\mathrm{d} 70$ to 120 , whereas increased mitochondrial biogenesis and sympathetic innervation of BAT occurs thereafter until parturition at d 150 [19]; this was confirmed in bovine BAT [20]. Relative UCP1 expression in ovine perirenal BAT reaches a peak at birth and then declines rapidly postnatally in lambs [21] and calves [20]. 
Giralt et al [22] examined ontogenic changes in type II thyroxine 5'-deiodinase activity in bovine BAT, which first appeared in fetal perirenal BAT at $\mathrm{d} 60$ of gestation and increased rapidly until reaching a peak at $\mathrm{d} 210$ of gestation. Giralt et al [22] hypothesized that endogenous production of $\mathrm{T}_{3}$ may be involved in prenatal induction of UCP1 expression in BAT; this subsequently was confirmed [23].

Treating rats with $\mathrm{T}_{3}$ for $5 \mathrm{~d}$ and then holding them at $22^{\circ} \mathrm{C}$ increased UCP1 expression in interscapular BAT [24]. Cold exposure increased interscapular BAT UCP1 expression, but under these conditions, $\mathrm{T}_{3}$ did not increase UCP1 expression further. In the current study, lambs from ewes fed the lowest supplemental $\mathrm{Cu}$ had the highest rectal temperatures and concomitantly the highest plasma $\mathrm{T}_{3}$. However, UCP1 expression was highest in lambs from ewes fed the high-Cu diets and in fact, UCP1 expression in BAT from the warmexposed lambs was detectable only in BAT of calves from high-Cu ewes. Furthermore, the electron micrographs suggest loss of cristae integrity in BAT of lambs from warm-exposed ewes. Thus, circulating $\mathrm{T}_{3}$ concentrations in the lambs may have been responsible for the elevated rectal temperatures in the low-Cu lambs, but did not appear to regulate $U C P 1$ gene expression.

\section{Norepinephrine and brown adipose tissue thermogenesis}

One of the key changes that occurs in BAT late in gestation is the development of sympathetic innervation [25], which increases the activity of thyroxine 5'-deiodinase [26,27]. In addition to its role in acute activation of BAT thermogenesis, $\mathrm{NE}$ also is involved in long-term modulation of BAT growth and development during cold stress by enhancing differentiation of BAT precursor cells, mitochondrial proliferation, and $U C P 1$ expression via $\beta_{3}$ - and $\alpha_{1}$-adrenergic receptor pathways [28]. Norepinephrine increases the activity of type II thyroxine 5 '-deiodinase and thereby promotes local production $\mathrm{T}_{3}$, which in turn increases UCP1 expression in BAT [26].

Consistent with the higher plasma $\mathrm{T}_{3}$ concentration in low$\mathrm{Cu}$ lambs, NE concentration also were higher in BAT from the low-Cu lambs. Unexpectedly, NE concentration was higher, and dopamine concentration was lower, in BAT from warmexposed lambs than in BAT from cold-exposed lambs. This may have been in response to increased NE secretion caused by elevated sympathetic stimulation.

\section{Cold exposure and brown adipose tissue thermogenesis}

We have investigated the postnatal changes in perirenal BAT in neonatal calves, and reported that COX activity of perirenal BAT was highest at birth and decreased substantially after $7 \mathrm{~d}$ of warm exposure [29]. Trayhurn et al [30] reported a similar postnatal decline in COX activity in warm-exposed, neonatal goats. The results of the current study confirm earlier observations, in that COX activity was approximately threefold higher in BAT of cold-exposed lambs than in warmexposed lambs. However, COX activity was unaffected by prenatal $\mathrm{Cu}$ supplementation.

Especially noteworthy was the greater decline in rectal temperature in lambs from high-Cu ewes (data pooled across chamber temperatures), in spite of their elevated BAT UCP1 gene expression. Cold exposure drastically depleted BAT lipid regardless of prenatal $\mathrm{Cu}$ exposure, and the electron micrographs suggest that any remaining lipid in BAT after cold exposure resided primarily in membrane phospholipids. The data indicate that BAT lipid stores of all cold-exposed lambs had been depleted rapidly, leading to an inability to further generate heat via BAT nonshivering thermogenesis. Plasma NEFA concentration was lower in cold-exposed lambs, which is consistent with the depletion of BAT lipid stores seen by $48 \mathrm{~h}$.

In conclusion, prenatal supplementation of $\mathrm{Cu}$ increased plasma $\mathrm{T}_{3}$ concentration and BAT UCP1 expression, but this may have caused reduced tolerance to cold exposure. The results of this study suggest that the inability of lambs to maintain body temperatures during extended cold exposure is due to depletion of lipid stores in BAT. The data of the current study indicate that, if lambs are born at a time when ambient temperatures are near freezing, they have only limited ability to maintain body temperature via non-shivering, BAT thermogenesis. Conversely, lambs born in warm environments maintain their lipid stores, but rapidly lose capacity for BAT thermogenesis, as reflected by loss of UCP1 expression by 48 $\mathrm{h}$ of age. Prenatal $\mathrm{Cu}$ supplementation delays the loss of UCP1 expression, but that may exacerbate body heat loss during cold exposure. What could not be determined from the current study was the mechanism of action by which increasing maternal intake of $\mathrm{Cu}$ enhanced $U C P 1$ gene expression in BAT of the newborn lambs.

\section{CONFLICT OF INTEREST}

We certify that there is no conflict of interest with any financial organization regarding the material discussed in the manuscript.

\section{ACKNOWLEDGMENTS}

This work was supported by Texas AgriLife Research, College of Agriculture and Life Science, Texas A\&M University.

\section{REFERENCES}

1. Stott AW, Slee J. The effect of environmental temperature during pregnancy on thermoregulation in the newborn lamb. Anim 
Prod 1985;41:341-7. https://doi.org/10.1017/S00033561000 36394

2. Cassard-Doulcier AM, Gelly C, Fox N, et al. Tissue-specific and beta-adrenergic regulation of the mitochondrial uncoupling protein gene: control by cis-acting elements in the 5 , flanking region. Mol Endocrinol 1993;7:497-506. https://doi. org/10.1210/mend.7.4.8388995

3. Leonard JL, Mellen SA, Larsch PR. Thyroxine 5'-deiodinase activity in brown adipose tissue. Endocrinology 1983;112:11535. https://doi.org/10.1210/endo-112-3-1153

4. Masaki T, Yoshimatsu H, Kakuma T, Hidaka S, Kurokawa M, Sakata T. Enhanced expression of uncoupling protein 2 gene in rat white adipose tissue and skeletal muscle following chronic treatment with thyroid hormone. FEBS Lett 1997;418: 323-6. https://doi.org/10.1016/S0014-5793(97)01404-X

5. Eales FA, Gilmour JS, Barlow RM, Small J. Causes of hypothermia in 89 lambs. Vet Rec 1982;110:118-20. http://dx.doi. org/10.1136/vr.110.6.118

6. Lukaski HC, Hall CB, Marchello MJ. Body temperature and thyroid hormone metabolism of copper-deficient rat. J Nutr Biochem 1995;6:445-51. https://doi.org/10.1016/0955-2863(95) 00062-5

7. National Research Council. Nutrient requirements of sheep. 6th ed. Washington DC, USA: National Academy Press; 1985.

8. Agricultural Research Council. The nutrient requirement of ruminant livestock, Commonwealth Agricultural Bureaux. London, UK: The Cresham Press; 1980.

9. Martin GS, Carstens GE, King MD, Eli AG, Mersmann HJ, Smith SB. Metabolism and morphology of brown adipose tissue from Brahman and Angus newborn calves. J Anim Sci 1999;77:388-99. https://doi.org/10.2527/1999.772388x

10. Chen C, Carstens GE, Gilbert CD, et al. Dietary supplementation of high levels of saturated and monounsaturated fatty acids to ewes during late gestation reduces thermogenesis in newborn lambs by depressing fatty acid oxidation in perirenal brown adipose tissue. J Nutr 2007;137:43-8. https://doi.org/10. 1093/jn/137.1.43

11. Cannon B, Lindberg O. Mitochondria from brown adipose tissue: isolation and properties. Methods Enzymol 1979;55:6578. https://doi.org/10.1016/0076-6879(79)55010-1

12. Billington CT, Bartness TJ, Briggs J, Levine AS, Morley JE. Glucagon stimulation of brown adipose tissue growth and thermogenesis. Am J Physiol 1987;252:R160-5. https://doi. org/10.1152/ajpregu.1987.252.1.R160

13. Burton KA. A study of the conditions and mechanism of the diphenylamine reaction for the colorimetric estimation of deoxyribonucleic acid. Biochem J 1956;62:315-23. https:// doi.org/10.1042/bj0620315

14. Markwell MN. A modification of the Lowry procedure to simplify protein determination in membrane and lipoprotein samples. Anal Biochem 1978;87:206-10. https://doi.org/10. 1016/0003-2697(78)90586-9
15. Houchin OB. A rapid colorimetric method for the quantitative determination of copper oxidase activity (ceruloplasmin). Clin Chem 1958;4:519-23.

16.Clarke L, Bird JA, Lomax M, Symonds ME. Effect of $\beta_{3}$-adrenergic agonist (Zeneca D7114) on thermoregulation in nearterm lambs delivered by cesarean section. Pediatr Res 1996;40: 330-6. https://doi.org/10.1203/00006450-199608000-00023

17.SAS Institute Inc. SAS user's guide: basics. 1982 ed. Cary, NC, USA: SAS Institute Inc.; 1985.

18. Kincaid RL, White CL. The effects of ammonium tetrathiomolybdate intake of tissue copper and molybdenum in pregnant ewes and lambs. J Anim Sci 1988;66:3252-8. https://doi.org/ $10.2527 /$ jas $1988.66123252 \mathrm{x}$

19. Alexander G. Quantitative development of adipose tissue in foetal sheep. Aust J Biol Sci 1978;31:489-503.

20. Landis MD, Carstens GE, McPhail EG, et al. Ontogenic development of brown adipose tissue in Angus and Brahman fetal calves. J Anim Sci 2002;80:591-601. https://doi.org/10.2527/ 2002.803591x

21. Pope M, Budge H, Symonds ME. The developmental transition of ovine adipose tissue through early life. Acta Physiol 2014; 210:20-30. https://doi.org/10.1111/apha.12053

22. Giralt M, Casteilla L, Viñas $\mathrm{O}$, et al. Iodothyronine $5^{\prime}$-deiodinase activity as an early event of prenatal brown-fat differentiation in bovine development. Biochem J 1989;259:555-9. https://doi.org/10.1042/bj2590555

23. de Jesus LA, Carvalho SD, Ribeiro MO, et al. The type 2 iodothyronine deiodinase is essential for adaptive thermogenesis in brown adipose tissue. J Clin Invest 2001;108:1379-85. https:// doi.org/10.1172/JCI13803

24. Petrovic N, Cvijic G, Davidovic V. Thyroxine and tri-iodothyronine differently affect uncoupling protein- 1 content and antioxidant enzyme activities in rat interscapular brown adipose tissue. J Endocrinol 2003;176:31-8. https://doi.org/10.1677/ joe.0.1760031

25. Henry BA, Loughnan R, Hickford J, Young IR, St. John JC, Clarke I. Differences in mitochondrial DNA inheritance and function align with body conformation in genetically lean and fat sheep. J Anim Sci 2015;93:2083-93. https://doi. org/10.2527/jas.2014-8764

26. Bianco AC, Carvalho SD, Carvalho CR, Rabelo R, Moriscot AS. Thyroxine 5'-deiodination mediates norepinephrineinduced lipogenesis in dispersed brown adipocytes. Endocrinology 1998;139:571-8. https://doi.org/10.1210/endo.139. 2.5737

27.Wu SY, Merryfield ML, Polk DH, Fisher DA. Two pathways for thyroxine 5'-monodeiodination in brown adipose tissue in fetal sheep: ontogenesis and divergent responses to hypothyroidism and 3,5,3'- triiodothyronine replacement. Endocrinology 1990;126:1950-8. https://doi.org/10.1210/endo-1264-1950

28. Geloen A, Collet AJ, Guay G, Bukowiecki LJ. Beta-adrenergic 
stimulation of brown adipocyte proliferation. Am J Physiol 1988;254:C175-82. https://doi.org/10.1152/ajpcell.1988.254. 1.C175

29. Smith SB, Carstens GE. Ontogeny and metabolism of brown adipose tissue in livestock species. In: Burrin D, Mersmann HJ, editors. Biology of metabolism in growing animals. Oxford,
UK: Elsevier Science Publishers; 2005. p. 303-22. https://doi. org/10.1016/S1877-1823(09)70019-0

30.Trayhurn PM, Thomas MEA, Keith JS. Postnatal development of uncoupling protein, uncoupling protein mRNA, and GLUT4 in adipose tissues of goats. Am J Physiol 1993;265: R676-82. https://doi.org/10.1152/ajpregu.1993.265.3.R676 